\title{
PEMBERDAYAAN USAHA KECIL MENENGAH BERBASIS AGRIBISNIS MENUJU PERTUMBUHAN EKONOMI BERMUTU DI JABAR
}

\author{
Munadjat Wardoyo ${ }^{1}$, Nining Harnani ${ }^{2}$ \\ ${ }^{1}$ Sekolah Arsitektur, Perencanaan dan Pengembangan Kebijakan Institut Teknologi Bandung \\ ${ }^{2}$ Univesitas Winayamukti munadjat@sappk.itb.ac.id
}

\begin{abstract}
Renewal of new economic rapidly expanding in recent years is a model of economic trade renewal known as green economy. The green economy is contracted with the model of economic renewal in the form of fossils as fuel, the origin of natural gas, oil and coal. The fundamental green economy of expertise and technology that aims to be the linkage of the human resource ecosystem that can minimize trade activity, the human economy on climate tranformation, global hot weather. West Java is known as a province that is trepopulous in Indonesia, as well as the province that has the economic growth potential of the community through small and medium enterprises (UKM) based on agribusiness which is relatively very much, especially UKM farm Enterprises Chicken and quail) that until now the existence is still not noticed by the government. Small and medium enterprises are still relatively not optimal management, because the cost of production of poultry feedings and production is relatively high compared to the purchasing power of people in the production, this is the subject matter To be examined in this research. This study aims to find out the green economy, clean production, and creative economy developed by small businesses of poultry farmers in West Java. aims to determine the role of trade, green economy, creative economic efforts in In West Java. Generate an empirical model of creative economic effort, clean products, trade, green economy, in an effort to promote quality economic growth. The methods used in this study are qualitative methods that include directional interviews (INDEBT interviews), focus group Discussion (FGD), and triangulation (experts, entrepreneurs, and society/consumers). Quantitative methods, including descriptive survey methods to illustrate the behavior of the variables studied, namely descriptions of creative ventures, clean products, green economy, clean production, and creative economic trade, then methods The survey includes the testing of causalaality between creative business, clean products, green economy, with a quality economic growth analysis tool used Structural Equation Model (SEM). The results of this research is desirable can give practical contribution, namely in the effort to help the West Java government program among others entrepreneurial development of 1000 community entrepreneurs in one year and the empowerment of small business poultry farmers who Less noted, whereas the contribution to the fulfillment of the needs of West Java and Indonesia is very high against the production of poultry meat and egg.
\end{abstract}

Keywords: Empowerment Small and Medium Enterprises, Quality Economy.

\begin{abstract}
ABSTRAK
Pembaharuan ekonomi baru yang berkembang cepat pada beberapa tahun belakangan ini merupakan model pembaharuan perdagangan ekonomi yang dikenal dengan ekonomi hijau (green economy). Ekonomi hijau dikontraskan dengan model pembaharuan ekonomi berupa fosil sebagai bahan bakar, diataranya gas alam, minyak dan.batubara. green economy mendasar tentang keahlian dan teknologi yang tujuan adalah keterkaitan ekosistem sumberdaya manusia yang dapat meminimalkan aktivitas perdagangan, ekonomi manusia terhadap tranformasi iklim, cuaca panas global. Jawa Barat yang dikenal merupakan Provinsi yang trepadat di Indonesia, serta Provinsi yang memiliki potensi pertumbuhan ekonomi masyarakat melalui Usaha Kecil dan Menengah (UKM) berbasis agribisnis yang relatif sangat banyak, terutama UKM usaha peternakan ayam kampung dan burung puyuh) yang sampai saat ini eksistensinya masih belum terperhatikan oleh Pemerintah. Usaha kecil menengah ini masih relatif belum optimal pengelolaannya, karena biaya produksi penggemukan unggas dan produksi telor relatif tinggi dibandingkan dengan daya beli masyarakat pada hasil produksi tersebut, hal ini yang merupakan pokok permasalahan yang akan dikaji pada penelitian ini. Penelitin ini bertujuan untuk mengetahui ekonomi hijau, produksi bersih, dan ekonomi kreatif yang dikembangkan oleh usaha kecil menengah peternak unggas di Jawa Barat.Bertujuan untuk mengetahui peran perdagangan, ekonomi hijau, usaha ekonomi kreatif dalam meningkatkan kenaian ekonomi bermutu di Jawa Barat. Menghasilkan suatu model empiris usaha ekonomi kreatif ,produk bersih ,perdagangan, ekonomi hijau , dalam upaya meningkatkan pertumbuhan ekonomi bermutu. Metode yang digunakan pada peneliian ini adalah metode kualitatif yang mencakup wawancara terarah (indebt interview), focus group discussion (FGD), dan triangulasi (pakar, pengusaha, dan masyarakat/ konsumen). Metode kuantitatif, mencakup metode deskriptif survey untuk menggambarkan perilaku variabel yang diteliti, yaitu deskripsi mengenai
\end{abstract}


usaha kreatif, produk bersih, ekonomi hijau, produksi bersih, dan perdagangan ekonomi kreatif, kemudian metode eksplanatori survey mencakup pengujian hubungan kausalaitas antara usaha kreatif,produk bersih, ekonomi hijau, dengan pertumbuhan ekonomi bermutu alat analisis yang yang dipakai Structural Equation Model(SEM). Hasil penelian ini diinginkan bisa memberikan kontribusi praktis, yaitu dalam upaya membantu program pemerintah Jawa Barat antara lain perkembangan UKM kewirausahaan masyarakat 1000 pengusaha dalam satu tahun dan pemberdayaan usaha kecil peternak unggas yang kurang terperhatikan, padahal kontribusi pemenuhan kebutuhan masyarakat Jawa Barat dan Indonesia sangat tinggi terhadap produksi daging unggas dan telor unggas tersebut.

Kata Kunci : Pemberdayaan UKM, Ekonomi Bermutu.

\section{PENDAHULUAN}

Pengembangan ekonomi baru yang berkembang cepat pada beberapa tahun belakangan ini merupakan model pembangunan ekonomi yang dikenal dengan ekonomi hijau (green economy). Dengan model Ekonomi hijau dikontraskan pengembangan ekonomi yang mengunggulkan gas alam,minyak bumi,batu bara,fosil sebagai bahan bakar.Ekonomi hijau sangat mendasar pada kepakaran teknologi bertujuan memiliki keterkaitan sumberdaya manusia ekosistem dan meminimalkan impek tindakan ekonomi khalayak terhadap perkembangan cuaca panas global.United Nation Environment Programme

(UNEP) membicarakan secara konsensus mendunia (a Global Green New Deal) pemerintah mampu membiayai transformasi ekonomi mengarah ekonomi makin hijau. Ekonomi hijau beritikad bisa sebagai solusi menangani perubahan iklim.

Sudariyono, yaitu Deputi Menteri nagara Lingkungan Hidup RI Bagian Pembaharuan Prasarana Teknis dan Pengembangan Kapasitas, menuturkan ekonomi hijau sanggup membarui sistem ekonomi yang memprioritaskan kegunaan jangka pendek dan merusak lingkungan,merupakan perekonomian makin ramah lingkungan. Labih lanjut Emil Salim, pakar Bidang Ekonomi dan Lingkungan menyebutkan, kegiatan ekonomi manusia sangat bergantung pada ekosistem alam.Kegiatan ekonomi yang buruk bisa berdampak pada pemanasan global (Tania, 2010). Kenaikan jumlah penduduk, perubahan kultur dan pergeseran masyarakat berakibat naiknya ajakan dan desakan terhadap sumberdaya lingkungan. Kekalahan pasar menimbulkan ekstenalitas, barang publik dan kepemilikan barang bersama serta kegagalan strategi sederhana diduga sebagai pemicu tingginya biaya yang harus dikeluarkan untuk pengamanan lingkungan.

Mengembangkan ekonomi hijau seperti investasi untuk bioteknologi, produk hemat energi, industri kreatif dan gaya hidup ramah lingkungan akan sangat membantu memperbaik kondisi lingkungan dan sekaligus meningkatkan kesejahteraan. Perhitungan Pendapatan Domestik Regional Bruto (PDRB) yang ramah lingkungan yang dikenal dengan PDRB Hijau yang telah diperkenalkan oleh BPS merupakan salah satu upaya serius dalam pengendalian dampak lingkungan.PDRB Hijau Indonesia untuk pembangunan nasional dapat 
memperhitungkan sumberdaya alam yang tersedia, jumlah yang dikonsumsi dan menghitung pengikisan sumberdaya alam yang terjadi juga dapat memperhitungkan berapa besar biaya yang diperlukan untuk melindungi lingkungan.

Dalam mekanisme pasar, aktivitas produksi dankonsumsi senantiasa menghasilkan limbah. Limbah yang terjadi yang tidak masuk dalam mekanisme pasarakan menghasilkan eksternalitas. Selama ini strategikonvensional dalam pengelolaan limbah masih cenderung bersifatreaktif,

$$
\text { yaitu bereaksi }
$$

setelah

terbentuknya limbah, bukan pada pencegahan ataupreventif, tetapi kuratif atau perbaikan setelah terjadi kerusakan atau pencemaran. Akibatnya diperlukan biaya tinggi untuk perbaikan kerusakan lingkungan, dan kerusakan lingkungan terus meningkat. Strategi ini idak dapat mengatasi masalah pencemaran yang sifatnya non-point source pollution. Karena sifatnya bereaksi setelah terjadi limbah, maka investasi dan biaya untuk pengolahan limbah relatif mahal.Hal ini yang sering dijadikan alasan oleh para pengusaha untuk tidak membangun instalasi pengolah limbah (http://estherbbn.wordpress.com).

Produksi bersih yang pertama kali diperkenalkan UNEP pada tahun 1989/1990 dan Bapedal 1995, merupakan salah satu paradigma baru dalam pengelolaan pencemaran lingkungan. Dalam setiap kegiatan pelaku didorong untuk menerapkan prinsip produksi bersih dengan aplikasi teknologi produksi bersih.
Jawa Barat yang dikenal merupakan Provinsi yang trepadat di Indonesia, serta Provinsi yang memiliki potensi pertumbuhan ekonomi masyarakat melalui pemberdayaan usaha kecil berbasis agribisnis yang relatif sangat banyak, terutama usaha kecil peternak unggas (usaha peternakan Ayam Kampung dan burung Puyuh) yang sampai saat ini eksistensinya masih belum terperhatikan oleh Pemerintah. Usaha kecil ini masih relative belum optimal pengelolaannya, karena biaya produksi penggemukan unggas relatif tinggi dibandingkan dengan daya beli masyarakat pada hasil produksi tersebut, hal ini yang merupakan pokok permasalahan yang akan dikaji pada penelitian ini.

Berdasarkan hasil survey awal (2014) pada 5 Kabupaten di Jawa Barat, yaitu Garut, Ciamis, Cianjur, Subang, dan Purwakarta, terrnyata, biaya produksi yang tinggi sebagai akibat dari pengolahan kotoran unggas yang kurang dikelola dengan baik, sehingga terjadi kegagalan dalam penggemukan unggas dan produksi telor yang kurang berkualitas.

Dalam mewujudkan Jawa Barat Green Province memiliki banyak tantangan:

1. Jumlah petambahan masyarakat, penduduk masih relatif besar.

2. Otonomi yang dipersepsikan kurang tepat oleh sementara pihak, seperti irigasi pertaian, pelanggaran lahan peruntukan, dan lainnya menunjukkan bahwa kesadaran para pihak terhadap arti penting penyelamatan lingkungan dipersepsikan sangat beragam. 
3. Perubahan gaya hidup dalam masyarakat terkait dengan komersialisme dan materialisme.

4. Produk ekspor juga harus memenuhi standar bebas pencemaran.

5. Pengembangan pertanian berkualitas juga harus didukung oleh kualitas lingkungan yang semakin tinggi.

6. Tingginya volume buangan limbah yang berasal dari rumah tangga dan juga limbah industri.

Berdasarkan uraian di atas, sangat penting untuk diteliti kegagalan pasar dapat menimbulkan pencemaran yang menimbulkan biaya tinggi dan bagaimana produksi bersih dapat menjamin peningkatan efisiensi industri serta terjaminnya kepentingan bersama dalam jangka panjang dan bagaimana produksi bersih mendukung pengembangan ekonomi kreatif dan sebaliknya, pada usaha kecil peternak unggas di Jawa Barat.

Berdasarkan latar belakang di atas, maka penelitian ini bertujuan untuk :

1. Mengetahui pertumbuhan ekonomi usaha kecil peternak unggas di Provinsi Jawa Barat.

2. Mengetahui peran ekonomi hijau, produksi bersih, dan ekonomi kreatif dalam meningkatkan pertumbuhan ekonomi berkualitas di Provinsi Jawa Barat.

\section{TINJAUAN PUSTAKA}

Program produk bersih yang dikembangkan berdasar pengetahuan dan teknologi sangat sejalan dengan pengembangan ekonomi kreatif. Ekonomi kreatif adalah proses peningkatan nilai tambah hasil dari eksploitasi kekayaan intelektual berupa kreativitas, keahlian dan bakat individu mejadi produk yang dapat dikomersiilkan. Pengembangan pola pikir ekonomi kreatif dapat dikembangkan dari pengertian industri kreatif. Creative industries are those industries which have their origin in individual creativity, skill and talent, and which have a potensial for wealth and job creation through the generation and exploitation of intellectual property and content (UK Creative Industries Taskforce, 1998).

Kekuatan industri kreatif berbasis UKM terletak pada aspek fleksibilitas akibat kecilnya skala usaha, besarnya kontribusi terhadap PDB dan kesempatan kerja serta kreatifitas sebagai input utama. Hal ini sejalan dengan hasil penelitian Sari dan Podesta (2008).Khusus untuk Jawa Barat yang memiliki sumber daya ternak yang baik, pilihan menempatkan pengembangan ekonomi kreatif yang berbasis pengembangan ekonomi rakyat dan berlandaskan usaha ternak unggulan merupakan pilihan strategis membangun ekonomi berbasis partisipasi masyarakat sekaligus membangun jati diri.Pola ini juga sekaligus menepis konsekuensi munculya fenomena persaingan tidak sehat, materialism dan komersialisme. Suatu produk yang berasal dari proses kreatif memiliki cirri- ciri siklus hidup yang singkat; memiliki resiko relatif tinggi; memiliki margin tinggi; 
memiliki keanekaragaman yang tinggi; memiliki persaingan yang tinggi.

Ekonomi kreatif yang sering pula disebut sebagai knowledge-based economy penciptaan nilai tambah produksi, distribusi, penggunaan atau aplikasi knowledge memainkan peran sangat dominan dalam seluruh aktivitas perekonomian. Knowledge base economy mendorong perusahaan menjadi lebih efisien dan kapitalisasi pasar menjadi lebih dinamis (Sampurno, 2007). Kini dan ke depan keberhasilan pembangunan ekonomi akan sangat tergantung pada penciptaan, penyebaran, dan aplikasi knowledge. Bangsa yang maju adalah bangsa yang mampu menghasilkan nilai tambah ekonomi yang besar melalui knowledge.Semua aktivitas ekonomi, betapapun sederhananya pada dasanya mengandung elemen ilmu pengetahuan.

Ciri khas pengembangan ekonomi berbasis knowledge adalah bermutu dan efisiensi. Peningkatan value added dari kegiatan ekonomi kreatif yang ditunjang produktivitas tinggi dan efisiensi diharapkan dapat melahirkan pertumbuhan yang cepat dan berkualitas. Kebijakan yang diperlukan adalah bagaimana agar pertumbuhan yang tercapai benar-benar searah dengan peningkatan pendapatan perkapita yang ditunjang dengan peningkatan kualitas tenaga kerja, dan pemerataan pendapatan.Apabila persentase produksi berbasis knowledge yang membentuk PDB meningkat secara meyakinkan dari tahun ke tahun berarti pertumbuhan ekonomi yang terjadi telah berbasis knowledge.Pertumbuhan ekonomi berkualitas berbasis knowledge, juga harus mencerminkan bahwa pertumbuhan tersebut menunjukkan peningkatan pemerataan pendapatan dan mempercepat penurunan jumlah penduduk miskin (Murjana Yasa, 2009).

Apabila produk kreatif yang dikembangkan adalah sekaligus juga mengikuti prinsipprinsip produksi bersih, maka peningkatan nilai tambah ekonomi yang terjadi akan sangat mendukung ekonomi hijau. Pertumbuhan ekonomi yang terjadi adalah pertumbuhan ekonomi berkualitas, tidak saja memenuhi kriteria kemerataan distribusi pendapatan dan orientasi pada penurunan penduduk miskin, tetapi sekaligus menjamin pengurangan resiko lingkungan.

Purwanto, mengadopsi UNEP menyebutkan strategi 1E4R (Elimination, Reduce, Reuse, Recycle,

Recovery/Reclaim).Prinsip-prinsip pokok dalam strategi produksi bersih dalam kebijakan Nasional Produksi Bersih (Kementerian Lingkungan Hidup, 2003; dalam Purwanto, 2005) dituangkan dalam 5R (Re-think, Re-use, Reduction, Recovery and Recycle).

1. Pengisolasian (pencegahan) adalah kekuatan untuk menghalangi timbulnya kotoran langsung dari asal muasalnya, mulai dari informasi baku, metode pembuatn sampai produk.

2. Berfikir ulang,merupakan konsep gagasan yang ada pada saat awal aktivitas akan berlangsung, dengan keterlibatan sebagai berikut. 
3. Inovasi dalam bentuk produksi dan pemakaian berlaku baik pada cara atau barang yang dihasilkan, sehingga harus kompeten betul penjabaran priode berfungsi produk.

4. Kekuatan keluaran bersih tidak dapat tercapai dilaksanakan tanpa adanya perbaikan dalam paradigma pikir, prilaku dan tingkah laku dari semua pihak terkait, yakni pemerintah, masyarakat, maupun dunia usaha;

5. Reduce (pengurangan) adalah upaya untuk menyusutkan atau merampingkan timbulnya kotoran pada asal muasalnya.

6. Reuse (memakai reduplikasi) adalah upaya mengizinkan suatu kotoran dapat memnanfaatkan kembali tanpa perlakuan biologi atau fisika,kimia

7. Daur ulang merupakan upaya priode ulang kotoran untuk menggunakan kotoran dengan membersihkan kembali ke prosedur semula denga perlakuan biologi dan kimia, fisika.

8. Recovery/Reclaim (memungut mengambil reduplikasi) adalah cara memungut bahan- bahan yang masih mempunyai nilai ekonomis tinggi dari suatu limbah, kemudian dikembalikan ke dalam proses produksi dengan atau tanpa perlakukan fisika, kimia dan biologi.

Purwanto lebih lanjut mengatakan, prinsip utama yang perlu ditekankan adalah pada pencegahan dan pengurangan (1E1R) atau $2 R$ pertama.Apabila strategi 1E1R atau 2R pertama masih menimbulkan pencemar atau limbah, baru kemudian dilakukan 3R berikutnya (reuse, recycle, dan recopery) sebagai suatu strategi tingkatan pengelolaan limbah.

Regulasi implementasi produksi bersih khususnya pada UKM dan Koperasi telah ditunjang oleh Peraturan Menteri Negara Koperasi, Usaha Kecil dan Menengah Republik Indonesia No. 26/Per/ M.KUKM/VI/2007 tentang Pedoman Teknis Bantuan Perkuatan untuk Teknologi Produksi Bersih dan Teknologi Tepat Guna Bagi Sentra Usaha Kecil dan Menengah. Tersedianya sentra-sentra UKM khususnya di kabupaten/kota di Jawa Barat sangat menunjang implementasi produksi bersih pada koperasi dan UKM ternak unggas.

Selain pemerintah, kerjasama luar negeri juga telah dirintis dalam implementasi produksi bersih. Clean Batik Initiative (CBI) yang dipakarsai EKONID, Perkumpulan Ekonomi Indonesia Jerman bekerja sama dengan PPBN (Pusat Prosuksi Bersih Nasional) dan dibiayai oleh the European Union.Tujuannya adalah untuk menghijaukan permintaan dan penawaran produk batik sekaligus memastikan bahwa dampak lingkungan telah diperhitungkan secara menyeluruh sehingga siklus produksi dan konsumsi yang disampaikan yang memiliki tanggung jawab moral dapat menjadi pelopor pengembangan industri batik yang berkelanjutan. Program ini terdiri atas tiga komponen, yaitu produksi berkelanjutan; konsumsi berkelanjutan; dan dialog kebijakan.Jumlah UKM Batik yang terlibat sekitar 500 yang tersebar di Jawa Barat, Jawa Tengah, DI Yogyakarta, Jawa Timur, 
Sulawesi Selatan dan Kalimantan Timur (http:// www.cleanbatik.com).

Penerapan produksi bersih sangat luas mulai dari kegiatan pengambilan bahan termasuk pertambangan, proses produksi, pertanian, perikanan, pariwisata, perhubungan, konservasi energi, rumah sakit, rumah makan, perhotelan, sampai pada sistem informasi (Purwanto, 2005). Industri Batik merupakan salah satu sektor yang termasuk dalam industri kerajinan yang dikembangkan sebagai sektor industri kreatif. Sektor lainnya adalah: Arsitektur; Pasar Seni dan Barang Antik; Desain; Fesyen; Film, Video, \& Fotografi; Permainan Kreatif; Musik; Seni Pertunjukan; Penerbitan dan Percetakan; Layanan Komputer dan Piranti Lunak; Radio dan Televisi; dan Riset \& Pengembangan. Khusus untuk Jawa Barat ada dua sektor penting yang perlu dikembangkan selain sektor di atas yaitu pertanian dan pariwisata.

\section{METODE}

Metode yang digunakan pada penelitian ini adalah metode kualitatif yang mencakup wawancara terarah (indebt interview), focus group discussion (FGD), dan triangulasi (pakar, pengusaha, dan masyarakat/ konsumen). Metode kuantitatif, mencakup metode deskriptif survey untuk menggambarkan perilaku variabel yang diteliti, yaitu deskripsi mengenai ekonomi hijau, produksi bersih, dan ekonomi kreatif, kemudian metode eksplanatori survey mencakup pengujian hubungan kausalaitas antara ekonomi hijau, produksi bersih, dan ekonomi kreatif dengan pertumbuhan ekonomi berkualitas dengan menggunakan alat analisis Structural Equation Model (SEM).

Unit analisis dalam penelitian ini adalah para pengusaha kecil peternak unggas di 5 Kabupaten di Provinsi Jawa Barat, yaitu Kabupaten Garut, Ciamis, Cianjur, Subang, dan Purwakarta yang dominan memiliki pengusaha kecil unggas terbanyak di Jawa Barat. Unit observasi dalam penelitian ini adalah para peternak unggas untuk penelitian kuantitatif(deskriptif dan verifikatif), serta pakar peternakan unggas, pemerintah daerah (dinas perindustrian), dan masyarakat (konsumen) untuk penelitian kualitatif (triangulasi, FGD, dan indebt interview).

\section{HASIL PENELITIAN DAN PEMBAHASAN}

\section{1) Pertumbuhan Ekonomi}

Pertumbuhan Ekonomi dalam penelitian ini merupakan suatu pencapaian yang diperoleh perusahaan dari aktivitas pemasaran yang dilakukannya.Sehingga dalam hal ini Pertumbuhan Ekonomi lebih tepat diukur melalui peningkatan produksi, peningatan hasil penjualan, dan kesejahteraan peternak. 
Tabel 1 : Pertumbuhan Ekonomi UKM ternak Unggas di Jawa Barat, 2015 (n=320)

\begin{tabular}{|c|l|c|c|}
\hline $\begin{array}{r}\text { No. } \\
\text { Item }\end{array}$ & \multicolumn{1}{|c|}{$\begin{array}{c}\text { Indikator } \\
\text { Pertumbuhan } \\
\text { Ekonomi }\end{array}$} & $\begin{array}{c}\text { Total } \\
\text { Skor }\end{array}$ & $\%$ \\
\hline PE.1 & $\begin{array}{l}\text { Dapat meningkatkan } \\
\text { kuantitas produksi total }\end{array}$ & 1262 & 16.43 \\
\hline PE.2 & $\begin{array}{l}\text { Dapat meningkatkan } \\
\text { kualitas produksi }\end{array}$ & 1268 & 16.51 \\
\hline PE.3 & $\begin{array}{l}\text { Dapat meningkat hasil } \\
\text { penjualan }\end{array}$ & 1294 & 16.85 \\
\hline PE.4 & $\begin{array}{l}\text { Dapat meningkatkan } \\
\text { laba perusahaan }\end{array}$ & 1284 & 16.72 \\
\hline PE.5 & $\begin{array}{l}\text { Dapat memperoleh } \\
\text { nasabah baru }\end{array}$ & 1286 & 16.74 \\
\hline PE.6 & $\begin{array}{l}\text { Dapat meningkatkan } \\
\text { kesejahteraan peternak }\end{array}$ & 1287 & 16.76 \\
\hline \multicolumn{2}{|l|}{ Total Skor } & $\mathbf{7 6 8 1}$ & $\mathbf{1 0 0 . 0 0}$ \\
\hline Rata-rata Total Skor & $\mathbf{1 2 8 0}$ & $\mathbf{1 6 . 6 7}$ \\
\hline
\end{tabular}

Berdasarkan tabel .1. di atas terlihat bahwa unsur Pertumbuhan Ekonomi UKM ternak unggas di Jawa Barat yang memiliki skor paling tinggi adalah dapat meningkatkan hasil penjualan.Sedangkan unsur Pertumbuhan Ekonomi yang paling rendah skornya adalah dapat meningkatkan kuantitas produksi total, hal ini menunjukkan bahwa pada umumnya peternak unggas di Jawa Barat mampu meningkatkan hasil penjualan, artinya permintaan pada telur ayam kampung dan puyuh itu tinggi, namun mereka kurang mampu meningkatkan kuantitas produksi, sehingga permintaan telur puyuh dan ayam kampung tidak mampu terlayani seluruhnya.

2) Peran ekonomi hijau, produksi bersih, dan ekonomi kreatif dalam meningkatkan pertumbuhan ekonomi berkualitas di Provinsi Jawa Barat.

Berdasarkan pada hasil analisis dengan Lisrel 8.30 tertuang pada gambar diagram jalur sebagai berikut :

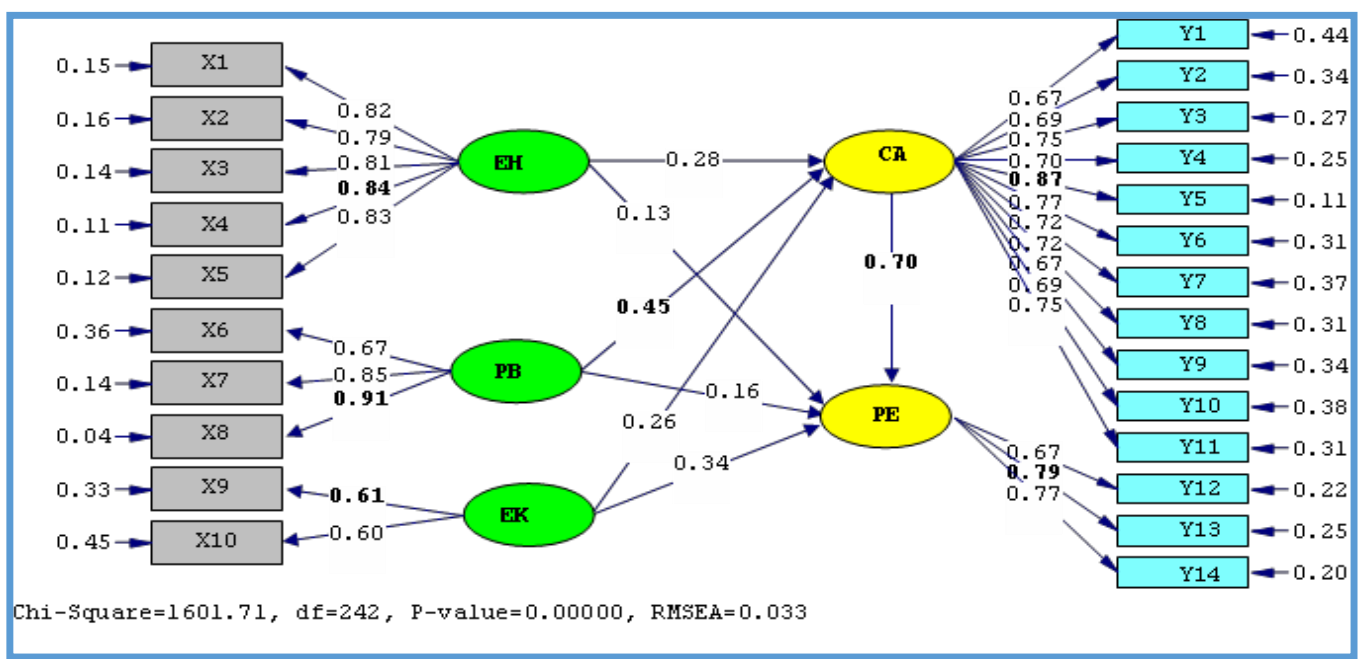

Gambar 1 : Diagram Struktural (Standardize) Pengaruh Ekonomi hijau, Produksi bersih, Ekonomi Kreatif, dan Keunggulan Bersaing terhadap Pertumbuhan Ekonomi 
Dimana :
$\mathrm{EH}=$ Ekonomi Hijau
$\mathrm{PB}=$ Produksi Bersih
EK = Ekonomi Kreatif
$\mathrm{CA}=$ Keunggulan Bersaing

$\mathrm{PE}=$ Pertumbuhan Ekonomi

Berikut ini merupakan t-value pada diagram jalur, seperti yang dinyatakan dalam Gambar 1 berikut ini :

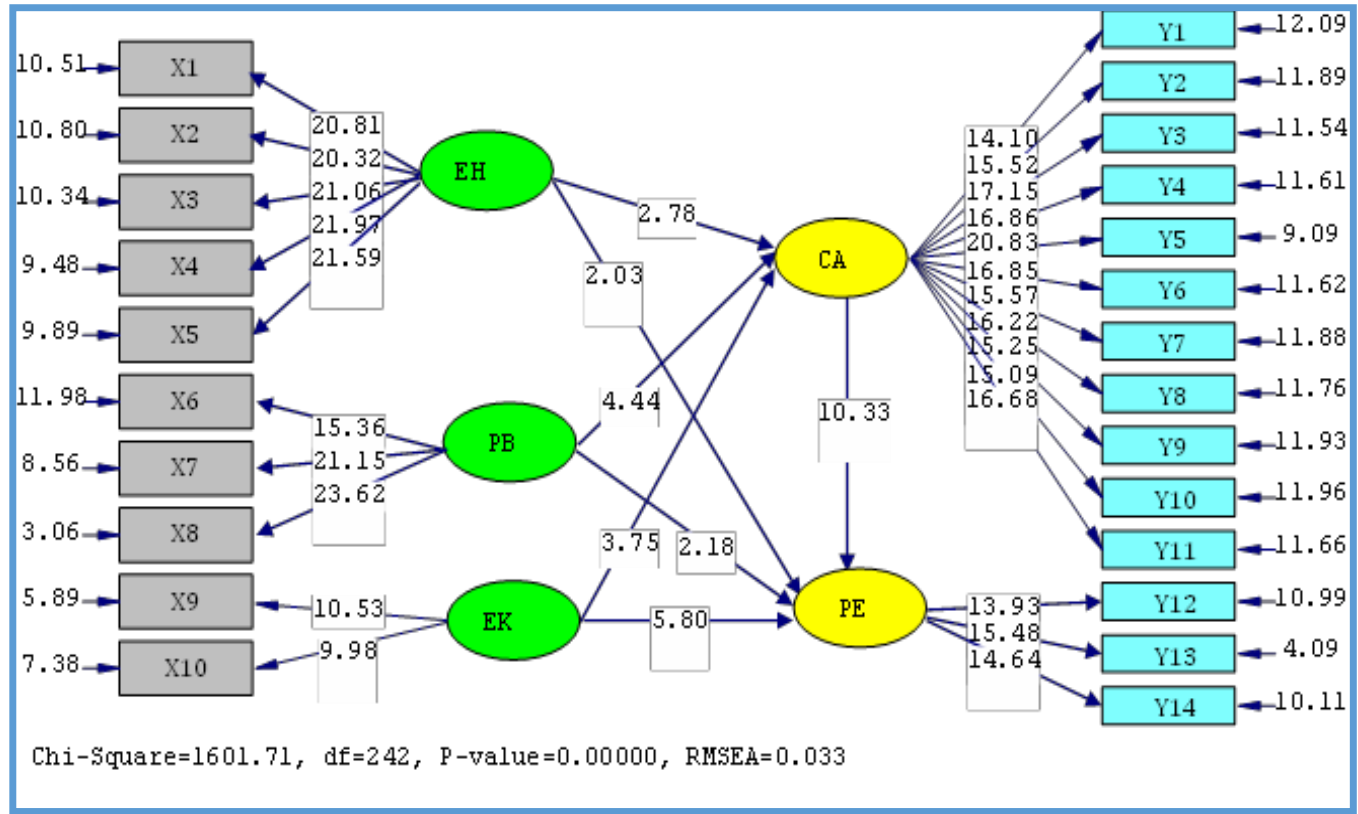

Gambar 2 : Diagram Struktural (t-value) Pengaruh Ekonomi hijau, Produksi bersih, Ekonomi Kreatif, dan Keunggulan Bersaing terhadap Pertumbuhan Ekonomi

Dimana :

$\mathrm{EH}=$ Ekonomi Hijau

$\mathrm{PB}=$ Produksi bersih

$\mathrm{EK}=$ Ekonomi Kreatif

$\mathrm{CA}=$ Keunggulan Bersaing

$\mathrm{PE}=$ Pertumbuhan Ekonomi

Dari Gambar 2 di atas diketahui bahwa pengaruh Ekonomi Hijau terhadap Pertumbuhan Ekonomi memiliki nilai $\mathrm{t}(2,03>2)$ yang signifikan, sehingga dapat disimpulkan bahwa pengaruh antara indikator dan variabel latennya serta pengaruh antara variabel laten eksogen yaitu Ekonomi Hijau terhadap variabel laten endogen yaitu Pertumbuhan Ekonomi adalah signfikan. Demikian juga pengaruh produksi bersih terhadap Pertumbuhan Ekonomi memiliki nilai t (2,18 > 2) berarti signifikan, sehingga dapat disimpulkan bahwa pengaruh antara indikator dan variabel latennya serta pengaruh antara variabel laten eksogen yaitu produksi bersih terhadap variabel laten endogen yaitu Pertumbuhan Ekonomi adalah signfikan. Selanjutnya pengaruh Ekonomi Kreatif terhadap Pertumbuhan Ekonomi memiliki nilai $\mathrm{t}$ $(5,80>2)$ berarti signifikan, sehingga dapat disimpulkan bahwa pengaruh antara indikator dan variabel latennya serta pengaruh antara variabel laten eksogen yaitu Ekonomi Kreatif terhadap variabel laten endogen yaitu Pertumbuhan Ekonomi adalah signfikan. Dan juga pengaruh keunggulan bersaing terhadap Pertumbuhan Ekonomi memiliki nilai $\mathrm{t}(10,33>2)$ yang signifikan, sehingga dapat disimpulkan bahwa pengaruh variabel laten endogen yaitu keunggulan bersaing terhadap variabel laten endogen yaitu Pertumbuhan Ekonomi adalah signfikan.

Berdasarkan di atas, maka temuan pada penelitian ini adalah bahwa Pertumbuhan Ekonomi UKM ternak unggas di Jawa Barat akan meningkat 
apabila UKM ternak memiliki keunggulan bersaing yang tinggi, keunggulan bersaing yang dimiliki UKM ternak akan menjadi unggul apabilaperusahaan memiliki produksi bersih yang efektif dan memiliki Ekonomi Hijau serta didukung Ekonomi Kreatif yang tepat.

\section{KESIMPULAN}

1. Para peternak unggas pada umumnya sudah memiliki budaya sehat, namun secara individu memiliki pola hidup yang kuang sehat, sehingga pola hidup sehat mereka harus ditingkatkan supaya telor puyuh dan telur ayam kampung yang dihasilkan lebih higienes untuk meningkatkan kualitas telurnya.Efesiensi produksi menjadi fokus utama para peternak unggas puyuh dan ayam kampung, namun mereka pada umumnya kurang memperhatikan akses bahan baku, artinya kurang dibangun kemitraan dengan para pedagang atau petani penghasil bahan pakan ayamdan puyuh.Para peternak unggas di Jawa Barat pada umumnya sudah mampu menciptakan nilai produk (telur ayam dan puyuh) sesuai keinginan konsumen, namun mereka pada umumnya masih belum tepat produk yang mereka kirimkan, sehingga telur ayam dan puyuh yang benar-benar kosumen pilih, itulah yang harus dikirimkan.

2. Pertumbuhan Ekonomi UKM ternak unggas di Jawa Barat akan meningkat apabilaUKM ternak memiliki keunggulan bersaing yang tinggi, keunggulan bersaing yang dimiliki UKM ternak akan menjadi unggul apabilaperusahaan memiliki produksi bersih yang efektif dan memiliki Ekonomi Hijau serta didukung Ekonomi Kreatif yang tepat.

DAFTAR PUSTAKA

Anonim. Penerapan Teknologi Produksi Bersih, Solusi Hemat
Energi.http://www.bppt.go.id. Diakses 26 Juni 2010.

2008.Produksi

Bersih. http://esthernbbn.wordpress.com.Diaks es 26 Juni 2010.

2009.Green Economy. http://en.wikipedia.org/wiki/Green_e conomy. diakses 26 Juni 2010.

Callan, Scott J. and Thomas, Janet M. 2000. Environmental Economics and Management: Theory,Policy,and Application.The DrydenPress.NewYork.

Clean Batik Initiative. Prakarsa Batik Bersih: Prakarsa Baru dalam Upaya Mendukung Lebih dari 500 UKM Batik di 6 provinsi di Indonesia. http://www.cleanbatik.com. Diakses, 15 Juli 2010.

Indrasti, N.S. dan A. M. Fauzi. 2009. Produksi Bersih. IPB Press, Bogor.

Nugraha, Winardi Dwi dan Ina Susanti. 2006. Studi Penerapan Prosuksi Bersih (Studi Kasus Pada Perushaan PULP And Paper Serang. Jurnal PRESIPITASI Vo. 1 No. 1. Hal. 43-48.

Kementrian Negara Koperasi dan Usaha Kecil dan Menengah Republik

Indonesia.2007. Peraturan Menteri Negara Koperasi dan Usaha Kecil dan Menengah Republik Indonesia Nomor 26/Per/M.KUKM/ VI/2007 Tentang Pedoman Teknis Bantuan Perkuatan Untuk Teknologi Prosuksi Bersih dan Teknologi Tepat Guna Bagi Sentra Usaha Kecil dan Menengah. Jakarta

Murjana Yasa, I G. W.(Ed.). 2009. Denpasar Kota Kreatif Berbasis Budaya Unggulan. Bappeda Kota Denpasar.

Purwanto. 2005. Penerapan Prosuksi Bersih di Kawasan

Industri.Makalah disampaikan pada Seminar Penerapan Program Prosuksi Bersih Dalam Mendorong Terciptanya Kawasan Eco-Industrial Indonesia, diselenggarakan oleh Asisten Deputi Urusan Standarisasi dan Teknologi.Jakarta, 3 Juni 2005 . 
Suada, I Ketut.2007. Produksi Bersih untuk Pengendalian Pencemaran.Makalah disampaikan pada Kursus Pengendalian Pencemaran.Denpasar tgl 22-27 Oktober 2007.

Suparmoko, M dan Suparmoko, Maria R. 2000. Ekonomi Lingkungan. BPFE, Yogyakarta.

Suyana Utama, Made. 2009. Integrasi Antara Aspek Lingkungan dan Ekonomi dalam Perhitungan PDRB Hijau pada Sektor Kehutanan di Kabupaten Karangasem Provinsi Bali.Bumi Lestari:Jurnal Lingkungan Hidup. Vo. 9. No. 2: 129-137.

Tania, Venny. 16 April 2010. Green Economy dan Perubahan Iklim. http://greenradio.fm. Diakses 25 Juni 2010 .

UNIDO. 2002. What is Cleaner Production http://www.unido.org. Diakses 26 Juni 2010 .

UNEP. 2003. Cleaner Production Assesment in Indonesia. http://www.uneptie.org. Diakses 26 Juli 2010.

. 22 Oktober 2008. Global Green New Deal- Environmentally- Focused Invesment Historic Opportunity for 21 st Century Prosperity and Job Generation. London/Nairobi. http://www.unep.org. Diakses 26 juni 2010. 